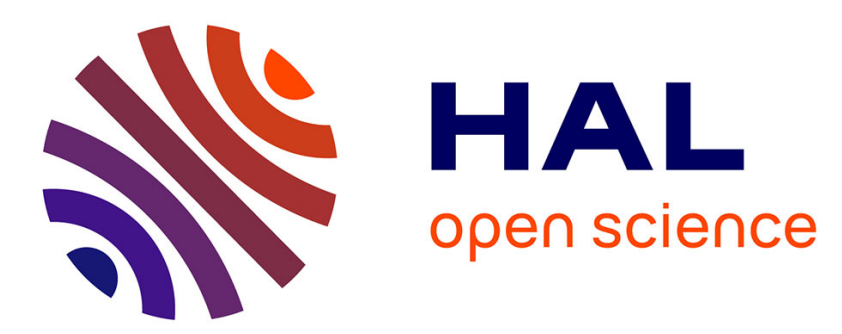

\title{
Stress field evolution above the Peruvian flat-slab (Cordillera Blanca, northern Peru)
}

\author{
Audrey Margirier, L. Audin, X. Robert, A. Pêcher, S. Schwartz
}

\section{To cite this version:}

Audrey Margirier, L. Audin, X. Robert, A. Pêcher, S. Schwartz. Stress field evolution above the Peruvian flat-slab (Cordillera Blanca, northern Peru). Journal of South American Earth Sciences, 2017, 77, pp.58-69. 10.1016/j.jsames.2017.04.015 . insu-01677069

\section{HAL Id: insu-01677069 https://hal-insu.archives-ouvertes.fr/insu-01677069}

Submitted on 16 Feb 2018

HAL is a multi-disciplinary open access archive for the deposit and dissemination of scientific research documents, whether they are published or not. The documents may come from teaching and research institutions in France or abroad, or from public or private research centers.
L'archive ouverte pluridisciplinaire HAL, est destinée au dépôt et à la diffusion de documents scientifiques de niveau recherche, publiés ou non, émanant des établissements d'enseignement et de recherche français ou étrangers, des laboratoires publics ou privés. 

northern Peru)

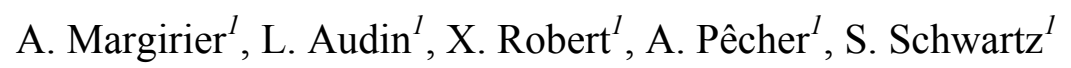

5

${ }^{1}$ Université Grenoble, Alpes, CNRS, IRD, ISTerre, F-38000 Grenoble, France

\section{Abstract}

In subduction settings, the tectonic regime of the overriding plate is closely related to the geometry of the subducting plate. Flat-slab segments are supposed to increase coupling at the plate interface in the Andes, resulting in an increase and eastward migration of the shortening in the overriding plate. Above the Peruvian flat-slab, a $200 \mathrm{~km}$-long normal fault trend parallel to the range and delimits the western flank of the Cordillera Blanca. In a context of flat subduction, expected to produce shortening, the presence of the Cordillera Blanca normal fault (CBNF) is surprising. We performed a systematic inversion of striated fault planes in the Cordillera Blanca region to better characterize the stress field above the Peruvian flat-slab. It evidences the succession of different tectonic regimes. NE-SW extension is predominant in most of the sites indicating a regional extension. We suggest that the Peruvian flat-slab trigger extension in the Western Cordillera while the shortening migrated eastward. Finally, we propose that flat-slab segments do not increase the coupling at the trench neither the shortening in the overriding plate but only favor shortening migration backward. However,

22 the stress field of the overriding plate arises from the evolution of plate interface properties 23 through time due to bathymetric anomaly migration.

\section{Key-works}


Inversion of striated fault planes; crustal stress field; mountain building; Peruvian flat-slab;

27 Cordillera Blanca

\section{Introduction}

The western South American margin is segmented along-strike, with changing Andean topography and slab dip variations (Barazangi and Isacks, 1976). Two flat-slab segments

32 have been identified by seismological data in northern Peru $\left(3-15^{\circ} \mathrm{S}\right)$ and central Chile (28$32^{\circ}$ S) (Barazangi and Isacks, 1976; Fig. 1). In such subduction settings, the tectonic regime of the overriding plate is closely related to the convergence direction, dip and geometry of the subducting plate (Ramos and Folguera, 2009). Around the world, flat-slab segments appear to increase coupling at the plate interface, resulting in both an increase and eastward migration of the shortening in the overriding plate (Jordan et al., 1983; Ramos and Folguera, 2009; Martinod et al., 2010).

Above the Peruvian flat-slab, a striking $200 \mathrm{~km}$-long normal fault trending parallel to the range delimits the western flank of the Cordillera Blanca high peaks (Bonnot, 1984; McNulty and Farber, 2002; Giovanni, 2007). Those peaks (>6000 m) are abnormally higher than the average plateau altitude at this place $(\sim 4400 \mathrm{~m})$. In such a context of flat subduction, expected to produce shortening, the joint presence of the Cordillera Blanca normal fault (CBNF) with high reliefs is surprising. Indeed, despite regional expected shortening related to the flat-slab subduction of the Nazca Plate beneath the South America, the Cordillera Blanca normal fault has been active during the Quaternary. Two models have been proposed to explain the occurrence of extension in this part of the high Andes: Dalmayrac and Molnar (1981) suggested an extensional collapse of a thickened crust, whereas McNulty and Farber (2002) involved oceanic ridge buoyancy under the Cordillera Blanca. Despite these models, the tectonic setting of the Cordillera Blanca emplacement is still debated: while Petford and Atherton (1992) suggested that the Cordillera Blanca batholith has emplaced in a dextral 
wrench regime based on ductile deformation structures, McNulty et al. (1998) interpreted some magnetic susceptibility data from the batholith as the result of a sinistral wrench regime. As this opposition extension versus along strike shearing is a key issue for Andean geodynamics (e.g., Dewey and Lamb, 1992; McNulty et al., 1998; Taylor et al., 1998; Scheuber and Gonzalez, 1999; Folguera et al., 2006, Audin et al., 2008), the aim of this paper is to precise and constrain the stress field evolution through time in this region with new microstructural data. Indeed, analyzing the ductile and brittle tectonic deformation in the crust permits to describe the impact of flat subduction on the stress field in the overriding plate in northern Peru. Moreover, the knowledge of the regional stress field evolution could provide information on processes driving the Cordillera Blanca batholith exhumation. The stress field evolution above the flat-slab is mainly inferred from inversions of striated fault planes measured on different outcrops in the Cordillera Blanca region.

\section{Geodynamic and tectonic context of northern Peru}

\subsection{Geodynamic setting}

The Andes are the result of the long-lasting subduction of the Nazca Plate beneath the South America Plate. The subduction zone has been active since at least Cretaceous time, with convergence rates, obliquity and subduction dip changing through time (e.g., Somoza, 1998; Ramos and Folguera, 2009; Martinod et al., 2010). These changes have been associated to different tectonic phases affecting the Andean range (e.g., Jordan et al., 1983; Pardo-Casas and Molnar, 1987; Somoza, 1998) and influenced the magmatic activity along strike (Kay and Kay, 2002; Ramos and Folguera, 2009).

The northern Peruvian margin displays a present-day flat subduction zone where both, the geometry and timing of slab flattening are well constrained for the last $15 \mathrm{Ma}$ (e.g., Gutscher et al., 1999; Hampel, 2002; Rosenbaum et al., 2005; Antonijevic et al., 2015). Gutscher et al. (2000) suggested that the flat-slab has a $\sim 20 \mathrm{~km}$ deep sag between the Nazca Ridge and the 
Inca Plateau thickened parts (Fig. 1). The subduction of these two buoyant features have been proposed to induce the slab flattening in northern Peru (Gutscher et al., 1999). Based on this hypothesis, several reconstructions of the timing and location of the initial Nazca Ridge subduction based on symmetric seafloor-spreading in a hotspot reference frame constrained the timing of the slab flattening (e.g., Hampel, 2002; McNulty and Farber, 2002; Rosenbaum et al., 2005; Antonijevic et al., 2015). However, all of these models rely on calculations of the motion of the Nazca Plate with respect to South America, which may induce considerable errors. Rosenbaum et al. (2005) presented a regionally refined plate circuit that suggests the initiation of the Nazca Ridge subduction at $15 \mathrm{Ma}$ at $10^{\circ} \mathrm{S}$ and the arrival of the Inca Plateau at $13 \mathrm{Ma}$ at $5^{\circ} \mathrm{S}$. This reconstruction, in agreement with the timing of magmatism migration eastward, indicates that the slab flattening occur at the latitude of the Cordillera Blanca region from $\sim 15 \mathrm{Ma}$.

\subsection{Peruvian tectonic history}

Several tectonic phases corresponding to short tectonic events that seems to have largely contributed to the Andean range building have been identified (Mégard, 1984). The first known major compressional event occurred in Late Albian, (113.0-100.5 Ma; Mégard, 1984). This tectonic phase, named Mochica, is recorded in the whole Western flank of the Central Andes (Jaillard, 1994) and is characterized by NE-SW compression (Mégard, 1984) likely associated with a dextral wrenching component (Bussel and Pitcher, 1985). It has been followed by a widespread episode of deformation in Peru, named the Peruvian phase, during the Santonian and the Campanian (86.3-70.6 Ma, NE-SW compression; Steinmann, 1929; Mégard, 1978; Gayet et al., 1991, Jaillard et al., 1993; Jaillard and Soler, 1996). An episode of uplift is likely contemporaneous with Peruvian phase in the Western Cordillera (Mégard, 1984). Then, from mid to late Eocene the main Andean shortening phase, the Incaic phase, caused extensive folding and reverse faulting in the Jurassic sediments of the Western 
Cordillera and the formation of a fold and trust belt along the Western Cordillera in Central Andes (48.6-33.9 Ma, NE-SW compression; Mégard, 1984; Noble et al., 1990).

106 The Neogene tectonic phase named the Quechua phase is divided in three discrete phases 107 (e.g., McKee and Noble, 1982; Mégard, 1984). The Quechua 1 phase (20-12.5 Ma) is

108 characterized by NW-SE shortening and by reactivation of structures inherited from the Incaic 109 phase in northern Peru, from the Western Cordillera to farther east. It seems that the 110 deformation associated with the Quechua 1 phase reached the Eastern Cordillera (Mégard, 111 1984). The Quechua 2 is bracketed between 9.5 and $8.2 \mathrm{Ma}$ in central Peru (Mégard et al., 112 1984). This phase is characterized by dextral strike-slip along NW-SE structures likely caused 113 by N-S compression (Soulas, 1977). Finally, the Quechua 3 phase identified in the subandean 114 fold and thrust belt ( 6 Ma; Mégard, 1984) is characterized by E-W compression (Soulas, 115 1977).

\subsection{Geologic and Quaternary tectonic settings of the Cordillera Blanca region}

The Cordillera Blanca and the Cordillera Negra are located in the northern Peruvian Andes, in the Western Cordillera (Fig. 1). The Cordillera Blanca is a Miocene granitic pluton (14-5 Ma; Mukasa, 1984; McNulty et al., 1998; Giovanni, 2007) emplaced in deformed Jurassic

121 sediments of the Chicama Formation at pressures ranging from 100 to $200 \mathrm{MPa}$ (Petford and 122 Atherton, 1992; Margirier et al., 2016). The Cordillera Blanca batholith and associated magmas, the Fortaleza and Yungay ignimbrites emplaced respectively around 7.4 Ma (Wipf, 2006) and between 8 and 3 Ma (Wise and Noble, 2003; Giovanni, 2007; Giovanni et al., 2010), correspond to the last magmatic activity before the cessation of magmatism associated to the slab flattening in northern Peru (Petford and Atherton, 1992).

127 The high summits of the Cordillera Blanca correspond to the footwall of the CBNF. The 128 elongated shape (trending parallel to the Andean range) and the internal fabric of the batholith suggest its emplacement along a pre-existing lithospheric fault structure, in a strike-slip 
context (Cobbing et al., 1981; Petford and Atherton, 1992; McNulty et al., 1998). However,

131 there is no consensus about the kinematics: dextral (based on ductile sub-solidus fabric in the

132 granite and on en-echelon structure in pegmatites; Petford and Atherton, 1992) versus

133 sinistral (from unclear AMS fabric; McNulty et al., 1998).

134 Preliminary studies addressed the Cordillera Blanca brittle tectonic history with microtectonic 135 data and stress reconstructions from fault slip dataset inversion (Bonnot, 1984; Sébrier et al., 136 1988). Bonnot (1984) proposed the succession of the following tectonic phases: (I) Pliocene 137 E-W extension ( $\sigma_{3}$ sub-horizontal N285, $\sigma_{1}$ sub-vertical), (II) Quaternary E-W compression $138\left(\sigma_{1}\right.$ sub-horizontal N080, $\sigma_{3}$ sub-vertical $)$ and N-S compression $\left(\sigma_{1}\right.$ sub-horizontal N150, $\sigma_{3}$ 139 sub-vertical), (III) N-S extension from the Pleistocene to present day ( $\sigma_{3}$ sub-horizontal N0, $140 \sigma_{1}$ sub-vertical). Sébrier et al. (1988) only focused on the last fault slip and suggested N-S 141 extension in the Cordillera Blanca. Neither the Quaternary compression nor the N-S extension 142 they evidenced in the Cordillera Blanca is in agreement with present day extensional 143 microseismicity (Deverchère et al., 1989).

144 The general trend of the Cordillera Blanca fault zone is $\mathrm{N} 140^{\circ}$ dipping $35-45^{\circ} \mathrm{SW}$. Variations 145 of the scarp heights and en echelon faulting in the southern part of the fault show that the 146 CBNF is segmented (Fig. 2; Giovanni, 2007). Field studies evidence discontinuous NW-SE 147 striking scarps that displace Quaternary glacial moraines as well as plutonic rocks (Fig. 3; 148 e.g., Bonnot, 1984; Schwartz, 1988). Along the fault zone, repeated displacements imprinted 149 the landscape, with $\sim 2$ to $>100$ m-high scarps, corresponding to vertical displacements 150 cumulated during the Quaternary (Fig. 3B, C) and $\sim 1 \mathrm{~km}$-high triangular facets (Fig. 3A). In 151 total, considering the emplacement depth of the Cordillera Blanca batholith, the scarps height 152 and the basin sedimentary filling thickness, the CBNF shows at least $4500 \mathrm{~m}$ of vertical 153 displacement in its central part since $\sim 5$ Ma (Bonnot, 1984; Giovanni, 2007; Margirier et al., 154 2016).

155 Based on thermochronologic data (apatite fission-tracks and apatite (U-Th)/He), Giovanni 
156 (2007) and Hodson (2012) gave estimation of exhumation rate at $\sim 2 \mathrm{~mm} / \mathrm{yr}$ and $>1 \mathrm{~mm} / \mathrm{yr}$

157 respectively on the central part of the CBNF and decreasing exhumation rates toward the

158 South for the last $3 \mathrm{Ma}$. For the last $4 \mathrm{Ma}$, Margirier et al. (2015), based on the same

159 thermochronologic systems, suggest lower exhumation rate $(1 \mathrm{~mm} / \mathrm{yr})$ for the central part of

160 the Cordillera Blanca. Even if modeling of thermochronologic ages did not indicate a well-

161 defined north-south trend in erosion rate (Margirier et al., 2016) the total exhumation since

162 the batholith emplacement decreases in the southern part of the Cordillera Blanca (Margirier

163 et al., 2016). Based on the CBNF morphology and the Cordillera Blanca geology Bonnot

164 (1984) estimated vertical slip rates of $\sim 0.7 \mathrm{~mm} / \mathrm{yr}$ on the CBNF between 3 and $0 \mathrm{Ma}$. On a

165 more recent time scale (30-0 ka), the CBNF displacement rates have been constrained by ${ }^{10} \mathrm{Be}$

166 dating of scarps (Siame et al., 2006) and geomorphic features (moraines) displaced by the

167 fault (Fig. 3B, C; Schwartz, 1988; Farber and Hancock, in prep). The vertical slip rates

168 decrease from north to south ranging from $5.1 \pm 0.8 \mathrm{~mm} / \mathrm{yr}$ to $0.6 \pm 0.2 \mathrm{~mm} / \mathrm{yr}$ (Fig. 2B;

169 Schwartz, 1988; Siame et al., 2006; Farber and Hancock, in prep).

170 In terms of seismic activity, no historical earthquake has been reported for the CBNF

171 (Silgado, 1992). However, some microseismicity occurs in the Cordillera Blanca region. The

172 focal mechanisms indicated present-day NE-SW extension in adequacy with Quaternary

173 offsets along the CBNF (Deverchère et al., 1989). The most significant coseismic surface

174 faulting has been reported in 1946 along the Quiches normal fault $(\mathrm{Mw}=6.8$; Doser, 1987;

175 Bellier et al., 1991), $50 \mathrm{~km}$ north-east from the CBNF trace. No significant seismic event

$176(\mathrm{Mw}>4)$ has been reported South of the CBNF segments neither along the Cordillera

177 Huayhuash neither farther South (Neotectonic Open Database ${ }^{1}$ ).

178 West of the Cordillera Blanca, the Callejón de Huaylas, an elongated range-parallel intra-

179 mountain basin (150 km long), builds the hanging wall of the CBNF and separates the

180 Cordillera Blanca and the Cordillera Negra. The sedimentary series filling this intra-mountain

\footnotetext{
${ }^{1}$ neotec-opendata.com
} 
181

182

183

184

185

186

basin recorded its subsidence associated to the CBNF initiation and activity (Bonnot, 1984).

Indeed, at the base of the series some ignimbrites dated at $5.4 \pm 0.1$ Ma suggest that normal faulting initiated at least at $5.4 \mathrm{Ma}$ (Giovanni, 2007, Giovanni et al., 2010). Westward, the Cordillera Negra consists of Cretaceous and Paleogene plutons (73-48 Ma; Mukasa, 1984; Beckinsale et al., 1985) intruded in the Chicama formation. Neogene volcano-sedimentary deposits capped the older formations in the southern part of the Cordillera Negra.

\section{Methods}

\subsection{Satellite image analysis}

In mountain ranges, the landscapes are largely controlled by the lithology and tectonic structures. Fracturing favors chemical weathering and weaken the rocks. Satellite imageries can be used to map fractures at up to kilometers scale in rocky landscapes/areas. Here, we analyzed satellite images (Google Earth, Landsat images, 2001-2002, visible band with a space resolution of $15 \mathrm{~m}$ ) to map the main faults at regional $/ \mathrm{km}$ scale (Fig. 2). Mapping displacements along active faults is based on displacement of surfaces or geomorphic markers such as moraines or Quaternary pediment surfaces. For each lineament we checked if it corresponds to a fault and not to a fold axis or a stratigraphy boundary (Fig. 2). To discuss the contradictory conclusions of previous works on the ductile deformation in the Cordillera Blanca (Petford and Atherton, 1992; McNulty et al., 1998), we also collected ductile deformation data in the field and from satellite image (Google Earth, Landsat images; Fig. 4).

\subsection{Tectonic stress inversion}

\subsubsection{Principe}

Several methods, based on sets of fault planes and slickenlines, permit to estimate paleostress tensors (e.g., Angelier and Mechler, 1977; Angelier, 1984). The reduced stress tensor, obtained from faults-slickenlines pairs inversion, provides the orientation of the principal 
stress axes $\sigma_{1}, \sigma_{2}, \sigma_{3}$ (with $\sigma_{1}>\sigma_{2}>\sigma_{3}$ and compression being positive) and a shape

208 parameter that we defined here as $P h i=\left(\sigma_{2}-\sigma_{3}\right) /\left(\sigma_{1}-\sigma_{3}\right)$ (e.g., Angelier, 1984; Delvaux and

209 Sperner, 2003). These inversion methods rely on three assumptions: (a) the stress is uniform

210 in the volume of rock considered, (b) the stress tensor is equivalent to the incremental

211 deformation tensor as obtained from the slip data, and (c) the slip vector on a fault plane

212 (given by the slickenlines) is parallel to the maximum shear stress along the plane as deduced 213 from the stress tensor (Bott, 1959). These assumptions imply careful choice of the 214 measurement stations, and brittle deformation measurements.

\subsubsection{Fieldwork}

217 We measured more than 400 couples fault-slickenline on 38 sites in the Cordillera Blanca 218 region (Table 1). For each site we measured between 2 and 34 striated fault planes 219 (supplementary tables A1 and A2, for all the planes we measured dip direction and dip angle) on outcrops no larger than $50 \mathrm{~m}$ with homogenous lithology. We measured all the striated

221 planes we have been able to see on the outcrops without selection. We constrained the 222 displacement direction and sense on each fault plane with classical tectoglyphs (fibers, 223 striations, steps...). For each measurement we attributed a qualitative confidence level for the 224 sense of the displacement found on the field (supplementary table A2). We kept only the 225 striated planes with unambiguous displacement sense. For "natural" outcrops, fault planes are 226 weathered and the slickenlines are not well preserved, leading to too few measurements to be 227 able to use them for analysis. Most of our sites are located along roads for quality of 228 outcroppings: it is constituted of fresh rocks and most of the faults-planes and slickenside 229 striae sets can be measured (orientation and dip). Measurement sites are mostly located in the 230 Cordillera Blanca but few stations are in the Cordillera Negra and the Callejón de Huaylas 231 (Fig. 2). This heterogeneous sampling is related to difficulties to find sites with competent, 232 fractured and low weathered rocks in the Cordillera Negra. 


\subsubsection{Inversion methods}

235 Different computer softwares are available to determine the reduced stress tensor that best

236 explains the slip distribution on a set of fault planes (e.g., TectonicsFP, FaultKinWin,

237 TENSOR, WinTensor, Mim; Marrett and Allmendinger, 1990; Sperner et al., 1993; Yamaji,

238 2000; Ortner et al., 2002; Delvaux and Sperner, 2003; Delvaux, 2012). As they are based on

239 the same physical concepts, all these methods are expected to give similar results (Delvaux

240 and Barth, 2010; Lacombe, 2012). The inversion of the data was here performed using the

241 software WinTensor (Delvaux, 2012) which inverts a dataset with the right dihedra method

242 (Angelier and Mechler, 1977) and the PBT method (Angelier, 1984). In the right dihedra

243 method an auxiliary plane is defined, orthogonal to the striated plane and to the striae. The

244 striated plane and the auxiliary plane define 4 right dihedras and 2 half spaces: a shortening

245 half-space and an extensional half-space, defined by the kinematic of the striaes. All results

246 are then superimposed and a statistical outline is used to calculate a tensor with $\sigma_{1}$ in dihedra

247 in compression and $\sigma_{3}$ in dihedra in extension. This initial result is used by the "Rotational

248 Optimisation" procedure that minimizes, by an iterative grid search, the misfit angle (Delvaux

249 and Sperner, 2003). Based on Wallace (1951) and Bott (1959) principles, the PBT method

250 considers that the slip vector on a fault plane is parallel to the maximum shear stress along the

251 plane. For each striated plane, compression and extension axis (P and T-axis) are constructed,

252 both lying in the plane given by the shear plane normal and the slickenline. In homogeneous

253 materials, $\sigma_{2}$ lies in the fault plane, and $\sigma_{1}$ and $\sigma_{3}$ in the plane containing the fault-plane

254 normal and the striae.

255 The inversion requires at least 5 fault-slickenline pairs. A higher number of data better

256 constrains the solution. Here, we used at least 6 pairs of fault-slickenline for an inversion. The

257 angular misfit between the measured slickenline and the theoretical slickenline predicted from

258 the calculated tensor is used as a quality indicator of the inversion (Fig. 5).

259 We processed the data following a multistep approach (Zeilinger et al., 2000). A random

260 tensor search was performed for each site (or grouped sites). The data is rejected when the 
misfit between the slickenline and the theoretical slickenline predicted from the calculated

262 tensor is $>30^{\circ}$. Then, all the rejected striated planes are recovered and the same procedure was

263 applied. Populations of less than 6 striated planes were considered not significant. For each

264 valley when our sites are close to each other (stations distributed in an area smaller than 10

$265 \mathrm{~km}$ ), we group the sites located in tectonically homogeneous units to process them as single 266 sites and average the regional stress field (Zeilinger et al., 2000; Pêcher et al., 2008). The 267 larger number of fault-slickenline pairs for grouped sites permits a more robust determination 268 of tensors.

\section{Results}

\subsection{Ductile deformation and local cooling ages of the Cordillera Blanca batholith}

272 We analyzed punctual ductile deformation evidences during the fieldwork and from satellite 273 images to discuss the tectonic context during the Cordillera Blanca batholith emplacement. 274 The granitic veins developed in the sediments close to the batholith contact are good 275 deformation markers ranging from field to satellite scale. Their ductile deformation provides a 276 reliable constraint of the upper plate regional strain axes contemporary of their emplacement. 277 Along the eastern limit of the Cordillera Blanca batholith, some deformed dykes intruded the 278 Jurassic sediments and indicates a dextral sense of shearing along the batholith (Fig. 2 and 279 4A). The surrounding granite is dated at $\sim 8 \mathrm{Ma}$ (zircon U-Pb and muscovite Ar-Ar; Giovanni, 280 2007).

281 In the Cordillera Blanca batholith a penetrative foliation and S-C structures indicates normal 282 top to SW sense of shearing. In addition, in the Canyon del Pato close to the contact between 283 the batholith and sediments, a dyke complex intrudes sedimentary rocks of the Chicama 284 Formation. Its ductile deformation indicates normal top to SW sense of shearing and NE-SW extension (shearing plane $=$ N145 30SW, stretching lineation $=$ N50 20SW; Fig. 4B). Close to this outcrop, the Cordillera Blanca batholith cooling is younger, ages range from 5 to $3.6 \mathrm{Ma}$ 


\subsection{Brittle deformation}

\subsubsection{The Cordillera Blanca normal fault}

291 Along strike the fault displays a well-defined scarp developed either in the bedrock, in

292 Quaternary alluvial fan, moraines or debris-flow deposits attesting of repeated displacements.

293 Field surveys evidence cumulative scarp height decreasing in lower and younger deposits, it 294 suggests multiple Holocene faulting events preserved on each sites. Southwards, the Holocene 295 fault scarp varies from a well-defined single scarp tens m-high to several sub-parallel en echelon faulting of about $1 \mathrm{~m}$-high. Punctually, the fault trace splits down in the Callejon de Huaylas into small graben and antithetic scarps, adjacent to the main scarp (Fig. 2). Northwards, the Quaternary scarp (strike $\mathrm{N} 140^{\circ}$ ) displays an impressive and constant westward dip of $\sim 35$ to $45^{\circ}$.

300 Along the CBNF several sites display striaes on the fault plane: from North to South, in Pachma Bajo, Quebrada Llaca and Quebrada Querococha (Fig. 2B). Striae on the fault have a down dip direction (N249-39SW). Tectoglyphs indicate a normal sense displacement (Fig. 5) consistent with the Quaternary displacement of the moraines along the CBNF (Dalmayrac and Molnar, 1981; Bonnot, 1984). This normal fault accommodates an ENE-WSW extension. Bonnot (1984) also reports bedrock slickensides along the fault scarp between Chiquian and Huaraz. He suggested that there might have been a sinistral component to the Quaternary slip on the fault segments striking N110 to N155. The en-echelon faults striking N140 in the southern part of the CBNF also suggest a sinistral component (Bonnot, 1984). However, the cumulated amount of such strike-slip component must be negligible because lateral offsets of moraine axes are not observed on the field.

\subsubsection{Example of a multistep deformation history in the Canyon del Pato}

313 In the Canyon del Pato, we collected data from 5 sites spread along a $5 \mathrm{~km}$-distance. All the 314 sites are located in the Cordillera Blanca batholith close to the CBNF (Fig. 2). We measured 
in this area 128 fault-slickenline pairs in the Neogene bedrock (Fig. 6). Here, a single stress

316 tensor cannot explain our data; the angular deviation is $>50^{\circ}$ for $\sim 50 \%$ of the data. The

317 important dispersion of fault orientations (Fig. 6) suggests a multistep brittle deformation

318 history. Following this hypothesis, we obtained 3 stress tensors from faults-slickenlines

319 inversion. Labeling T1, T2 and T3 refer only to the number of striated planes associated to

320 each tensor and didn't imply a chronology. The predominant tensor (T1, 66 faults)

321 corresponds to NE-SW pure extension (Fig. 6). The second stress tensor (T2, 12 faults) is

322 related to E-W transpression with a component in sinistral strike-slip. The less well-defined

323 third stress tensor (T3, 11 faults) corresponds to E-W pure extension. None of the T3 axes is

324 vertical indicating that this tensor has been tilted while $\mathrm{T} 1$ and $\mathrm{T} 2$ seem not tilted. It could

325 indicate that $\mathrm{T} 3$ is the older tensor.

\subsubsection{Regional stress fields}

328 Most of our measurements were taken in the Cordillera Blanca batholith. In addition, five

329 sites are located in the southern part of the Cordillera Blanca (Quebrada Pastoruri), in

330 sedimentary and volcanic rocks, one is in the Callejón de Huaylas (Caraz) and two sites are

331 located in the Cordillera Negra (Fortaleza Valley and Pueblo Libre). The results of stress

332 tensors for grouped sites are presented in the Table 1. For the best-defined tensor (T1) most of

333 the misfit are lower than $15^{\circ}$ demonstrating the quality of the inversion, for the other tensors

334 (T2 and T3) most of the misfit are lower than $20^{\circ}$.

335 The Cordillera Blanca brittle deformation reflects the recent stress field that is superimposed

336 on ductile deformation acquired during the Cordillera Blanca emplacement and early

337 exhumation. In most of the sites we found up to two tensors with different characteristics

338 (extension, wrenching and compression). The wide range of tensors suggests a multistep

339 brittle deformation history in the Cordillera Blanca region. The best-expressed stress tensor

340 corresponds to NE-SW extension ( $80 \%$ of the 38 sites; Figs. 7, 8A). The extension is not

341 restricted to the Cordillera Blanca. Indeed, the Pueblo Libre and the Fortaleza sites recorded 
342 respectively $\mathrm{E}-\mathrm{W}$ extension and transtension with horizontal $\mathrm{E}-\mathrm{W} \sigma_{3}$ axis. The stress

343 inversion also indicates wrenching (50\% of the sites), N-S extension (in Quebradas Ulta,

344 Querococha and Pastoruri, 30\% of the sites) and E-W compression (in Quebradas Llaca and

345 Ulta, $15 \%$ of the sites) (Figs. 7, 8). The E-W compression tensors indicate that a 346 compressional phase affect the Cordillera Blanca region after the Cordillera Blanca 347 emplacement. Therefore, after $\sim 8$ Ma several tectonic regimes followed one another in the 348 Cordillera Blanca region.

\section{Discussion}

\subsection{Tectonic context for the Cordillera Blanca emplacement}

352 Our ductile deformation data indicates two different strain regimes: a dextral strike-slip in the 353 eastern part of the Cordillera Blanca (Fig. 4A, see Fig. 2 for site location) and an E-W 354 extension close to the CBNF, in the northern part of the Cordillera Blanca (Fig. 4B). As the 355 Cordillera Blanca batholith displays different ages in these two sites and as the deformation 356 indicates two different strain regimes, these two regimes may result from different tectonic 357 phases.

358 First, the granite emplaced in a dextral strike-slip regime ( 8 Ma, Fig. 4A). Our data are here 359 in agreement with the ductile deformation evidenced by Petford and Atherton (1992). This 360 dextral strike-slip likely corresponds to a late stage of the Quechua 2 tectonic phase (9.5-8.5 $361 \mathrm{Ma}$ ) which is characterized by strike-slip movements on NW-SE faults resulting from N-S 362 compression (Mégard, 1984; Mégard et al., 1984).

363 Close to the CBNF the ductile deformation recorded NE-SW extension (Fig. 4B). In this area 364 the batholith is young $4.5 \mathrm{Ma}$ (Stewart et al., 1974; Giovanni, 2007); this NE-SW extension 365 exists at least since the Cordillera Blanca batholith emplacement and is consistent with the 366 initiation of the Callejón de Huaylas subsidence at 25.4 Ma associated to the CBNF activity (Bonnot, 1984; Giovanni, 2007). 
The Cordillera Blanca region recorded two steps of ductile deformation and a multistep brittle

371 deformation history. The identified stress fields are: NE-SW extension, N-S extension, E-W compression and $\sim$ E-W transtension (Table 1, Figs. 6, 8). Despite numerous markers of superposed movements on fault planes their relative chronology was unclear. It is not possible to reconstruct the chronology of stress field based on field criteria. Therefore, we compare calculated stress tensor with tectonic phases documented by Mégard (1984) in northern Peru and with the present day stress field inferred from microseismicity (Deverchère et al., 1989). The ductile deformation indicates a dextral strike-slip at $\sim 8 \mathrm{Ma}$ in the eastern part of the Cordillera Blanca. This deformation could be related to the Quechua 2 period, which has produced dextral strike-slip on NW-SE trending faults in Ayacucho basin between 9.5 and 8.5 Ma (Mégard et al., 1984). Then, the ductile NE-SW extension observed in the Canyon del 381 Pato ( $\sim 5 \mathrm{Ma})$ likely corresponds to the earlier brittle deformation NE-SW extensional tensors. This extension posterior to $\sim 4.5 \mathrm{Ma}$ is in agreement with the initiation of the CBNF at $\sim 5.4$ Ma (Bonnot, 1984). Moreover, this NE-SW extension is similar to the regional stress tensor deduced from a microseismicity survey (Deverchère et al., 1989). Thus, we suggest that these 385 ductile and brittle deformation phases are related to a state of stress identical to state of stress 386 observed at the present day in the Cordillera Blanca region. This state of stress was effective regionally at least for the last $\sim 5 \mathrm{Ma}$. The extensional stress tensors are not restricted to the 388 Cordillera Blanca. It likely corresponds to a large-scale process driving extension in the 389 overriding plate.

390 In addition, the less-expressed stress tensors indicate locally some anomalies in the stress 391 field. Indeed the brittle deformation also indicates that E-W compression episode in the 392 Cordillera Blanca batholith. This compressional episode is also recorded in the Callejón de 393 Huaylas basin (Bonnot, 1984). It could be related to the Pliocene Quechua 3 compressional 394 phase (Mégard, 1984) which could have trigger a brief compressional phase during the CBNF 395 activity (since $\sim 5.4 \mathrm{Ma}$ ). Finally, the brittle deformation also recorded multidirectional 
extension $(P h i<0.5)$ in the Cordillera Blanca (Quebrada Paron, Quebrada Querococha,

397 Quebrada Pastoruri). This stress field could be related to the Quaternary rapid exhumation of 398 the central part of the Cordillera Blanca (Margirier et al., 2016).

\subsection{Different tectonic phases above the Peruvian flat-slab}

401

402

403

404

This study evidence the occurrence of several tectonic phases above the Peruvian flat-slab segment during the past $8 \mathrm{Myr}$ in agreement with Bonnot (1984). These successive tectonic phases and the occurrence of predominant extension perpendicular to the trench suggest that flat-slab segments do not always induce compression in the upper plate as previously suggested (Jordan et al., 1983; Ramos and Folguera, 2009; Martinod et al., 2010). The tectonic regime changes may be associated to other parameters as plates velocities, plates directions, the absolute movement of the trench, the age of the oceanic plate, the presence of sediments or the geometry of the oceanic plate (e.g., Ruff and Kanamori, 1983; Heuret et al., 2007; Schellart, 2008). As the tectonic regime change occurs in a short period of time it could be linked to a local process (versus a large scale geodynamic process). The Peruvian flat slab geometry includes two thickened parts, the Nazca Ridge and the Inca Plateau, and a sag between these two features (Gutscher et al., 1999). Plate reconstructions indicated that the Nazca Ridge subduction initiate at $\sim 10^{\circ} \mathrm{S}$ at $\sim 15 \mathrm{Ma}$ and then the ridge migrate southward (Hampel, 2002; Rosenbaum et al., 2005; Antonijevic et al., 2015). The subduction of the Nazca Ridge below the Cordillera Blanca could have induced an increase of the coupling (e.g., Gutscher et al., 2000; McNulty and Farber, 2002; Martinod et al., 2010) and triggered compressional stress field in this area. After the migration of the ridge toward the South when the sag arrived below the Cordillera Blanca, the coupling could have decreased and permitted extension in the overriding plate. Indeed, Nocquet et al. (2014) demonstrated that the subduction segments of northern Peru show a low to weak interseismic coupling contrasting with the southern Peru region. Similarly, above the Mexican flat-subduction, Gérault et al. (2015) suggested the control of the mantle dynamic and of a weak subduction interface in the 
423

424

425

"neutral" state of stress. Finally, all flat slab segments do not trigger extension. For example, no extension have been reported above the Pampean flat-slab in Chile (e.g., Ramos et al., 2002), whereas the Nazca Plate have the same age and dip in these two segments (Barazangi and Isacks, 1976; Müller et al., 2008). The presence of an over-thickened crust ( 50 km, James, 1971) in Peru could favor extension independently of subduction properties (Froidevaux and Isacks, 1984). In addition, the amount of sediments on the oceanic plate is different in Peru and Chile: The sediment thickness reaches $\sim 500 \mathrm{~m}$ in Peru, in Chile there is no sediments (Divins, 2006). The presence of sediment can change the plate interface properties (Ruff, 1989). Indeed, in Peru GPS survey suggest the subduction interface is not homogeneously coupled along-strike with the existence of a $500 \mathrm{~km}$-long uncoupled segment in northern Peru whereas in southern Peru and Chile the subduction interface is characterized by highly coupled asperities separated by narrower zones of low interseismic coupling (Nocquet et al., 2014; Saillard et al., 2017).

\section{Conclusions}

Our data suggest a complex tectonic history in the Cordillera Blanca region. The analysis of ductile deformation in the eastern part of the Cordillera Blanca batholith ( $8 \mathrm{Ma})$ suggests that the batholith emplaced in a dextral strike-slip context according to Petford and Atherton (1992) observations. In a younger part of the Cordillera Blanca batholith ( 4.5 Ma) the ductile deformation indicates NE-SW extension. Then, the multistep deformation recorded in the Cordillera Blanca indicated the succession of different tectonic regimes (dextral strike-slip, NE-SW extension, E-W compression and NE-SW extension) above the Peruvian flat-slab. The presence of the crustal-scale CBNF and our NE-SW extensional stress tensor suggest that flat subduction can trigger extension in the Western Cordillera while in the Eastern Cordillera the shortening migrate eastward (Mégard, 1984). The extension may be facilitated by the presence of a thickened crust in Peru (Froidevaux and Isacks, 1984), an absolute movement of the overriding plate toward the trench or by a decrease of the convergence rate and a low 
coupling at the plate interface (Somoza, 1998; Nocquet et al., 2014). In the context of the

long-lasting subduction of the Nazca Plate, we suggest that the change of tectonic regime in the overriding plate (from compression to extension) and the extension along the CBNF are likely associated to a decrease of the coupling at the plate interface at the trench and below the Western Cordillera while the shortening migrates eastwards. Finally, considering the occurrence of extension along the CBNF since 5.4 Ma and the predominant NE-SW extension regime, we suggest that flat-slabs do not always favor shortening in the overriding plate. The Peruvian flat-slab seems to not increase the coupling at the trench but only increase the coupling eastward and favor shortening migration in the subandean region.

\section{Acknowledgments}

This work was supported by a grant from LabEx OSUG@2020 (Observatoire des Sciences de l'Univers de Grenoble, Investissements d'Avenir, ANR10 LABX56), and SMINGUE. We thank the SERNAMP for allowing access to the Cordillera Blanca National Park. We acknowledge the editor, C. Costa and the anonymous reviewer for their constructive comments of this manuscript.

\section{References}

Angelier, J. (1984), Tectonic analysis of fault slip data sets, Journal of Geophysical Research: Solid Earth, 89(B7), 5835-5848.

Angelier, J., and P. Mechler (1977), Sur une methode graphique de recherche des contraintes principales également utilisables en tectonique et en séismologie: la méthode des dièdres droits, Bulletin de la Société Géologique de France, 19(6), 1309-1318.

Antonijevic, S. K., L. S. Wagner, A. Kumar, S. L. Beck, M. D. Long, G. Zandt, H. Tavera, and C. Condori (2015), The role of ridges in the formation and longevity of flat slabs, Nature, 524(7564), 212-215, doi:10.1038/nature14648.

Audin, L., P. Lacan, H. Tavera, and F. Bondoux (2008), Upper plate deformation and seismic barrier in front of Nazca subduction zone: The Chololo Fault System and active tectonics along the Coastal Cordillera, southern Peru, Tectonophysics, 459 (1-4) 1, 174-185, doi:10.1016/j.tecto.2007.11.070.

480 Barazangi, M., and B. L. Isacks (1976), Spatial distribution of earthquakes and subduction of 
the Nazca plate beneath South America, Geology, 4(11), 686-692.

482

Beckinsale, R. D., A. W. Sanchez-Fernandez, M. Brook, E. J. Cobbing, W. P. Taylor, and N. B. Moore (1985), Rb-Sr whole rock isochron and K-Ar determination for the Coastal Batholith of Peru, in Magmatism at a Plate Edge: The Peruvian Andes, edited by W. S. Pitcher, M. P. Atherton, E. J. Cobbing, and R. D. Beckinsale, pp. 177-202, Blackie Halstead press, Glasgow.

Bellier, O., J. F. Dumont, M. Sébrier, and J. L. Mercier (1991), Geological constraints on the kinematics and fault-plane solution of the quiches fault zone reactivated during the 10 November 1946 Ancash earthquake, northern Peru, Bulletin of the Seismological Society of America, 81(2), 468-490.

Bonnot, D. (1984), Néotectonique et tectonique active de la Cordillère Blanche et du Callejon de Huaylas (Andes nord-péruviennes), Thèse présentée pour obtenir le grade de docteur, Université de Paris-Sud, Centre d'Orsay, 1-202.

Bott, M. (1959), The mechanics of oblique slip faulting, Geol. Mag.

Bussel, M.A. and W. S. Pitcher (1985), The structural control of batholith emplacement. In Magmatism at a Plate Edge, the Peruvian Andes, edited by W.S. Pitcher, M.P. Atherton, E. J. Cobbing and R.D. Beckinsale, pp. 167-176, Blackie Halstead Press, London.

Cobbing, J., W. Pitcher, J. Baldock, W. Taylor, W. McCourt, and N. J. Snelling (1981), Estudio geológico de la Cordillera Occidental del norte del Perú, Instituto Geologico Minero y Metalurgico, Serie D. Estudios Especiales, 10(D), 1-252.

Dalmayrac, B., and P. Molnar (1981), Parallel thrust and normal faulting in peru and constraints on the state of stress, Earth and Planetary Sciences Letters, 55, 473-481.

Delvaux, D. (2012), Release of program Win-Tensor 4.0 for tectonic stress inversion: statistical expression of stress parameters, EGU General Assembly Conference Abstracts.

Delvaux, D., and A. Barth (2010), African stress pattern from formal inversion of focal mechanism data, Tectonophysics, 482, 105-128, doi:10.1016/j.tecto.2009.05.009.

Delvaux, D., and B. Sperner (2003), New aspects of tectonic stress inversion with reference to the TENSOR program, Geological Society, London, Special Publications, 212(1), 75100, doi:10.1144/GSL.SP.2003.212.01.06.

Deverchère, J., C. Dorbath, and L. Dorbath (1989), Extension related to a high topography: results from a microearthquake survey in the Andes of Peru and tectonic implications, Geophysical Journal International, 98(2), 281-292.

Dewey, J. F., and S. H. Lamb (1992), Active tectonics of the Andes, Tectonophysics, 205(1), 79-95.

Divins, D. L. (2006), Total sediment thickness of the world's oceans and marginal seas,

Doser, D. I. (1987), The Ancash, Peru, earthquake of 1946 November 10: evidence for lowangle normal faulting in the high Andes of northern Peru, Geophysical Journal of the Royal Astronomical Society, 91, 57-71.

Farber, D. L., G. S. Hancock (in prep), Tectonic and glacial forcing of motion along an active detachment fault. 
Folguera, A., T. Zapata, and V. A. Ramos (2006), Late Cenozoic extension and the evolution of the Neuquén Andes, Geological Society of America special papers, 407, 267-285.

Froidevaux, C., and B. L. Isacks (1984), The mechanical state of the lithosphere in the Altiplano-Puna segment of the Andes, Earth and Planetary Science letters, 71(2), 305314.

Gayet, M., L. G. Marshall, and T. Sempéré (1991), The Mesozoic and Paleocene vertebrates of Bolivia and their stratigraphic context: a review, in Fósiles y Facies de Bolivia, edited by R. Suárez, 12(3-4), 393-433.

Gérault, M., L. Husson, M. S. Miller, and E. D. Humphreys (2015), Flat - slab subduction, topography, and mantle dynamics in southwestern Mexico, Tectonics, doi:10.1002/(ISSN)1944-9194.

Giovanni, M. K. (2007), Tectonic and Thermal Evolution of the Cordillera Blanca Detachment System, Peruvian Andes: Implication for Normal Faulting in a Contractionnal Orogen, 1-255 pp. University of California, Los Angeles.

Giovanni, M. K., B. K. Horton, C. N. Garzione, B. McNulty, and M. Grove (2010), Extensional basin evolution in the Cordillera Blanca, Peru: Stratigraphic and isotopic records of detachment faulting and orogenic collapse in the Andean hinterland, Tectonics, 29(6), TC6007, doi:10.1029/2010TC002666.

Gutscher, M. A., J. Malavieille, S. Lallemand, and J.-Y. Collot (1999), Tectonic segmentation of the North Andean margin: impact of the Carnegie Ridge collision, Earth and Planetary Science letters, 168(3), 255-270.

Gutscher, M.-A., W. Spakman, H. Bijwaard, and E. R. Engdahl (2000), Geodynamics of flat subduction: Seismicity and tomographic constraints from the Andean margin, Tectonics, $19(5), 814-833$.

Hampel, A. (2002), The migration history of the Nazca Ridge along the Peruvian active margin: a re-evaluation, Earth and Planetary Science letters, 203(2), 665-679.

Heuret, A., F. Funiciello, C. Faccenna, and S. Lallemand (2007), Plate kinematics, slab shape and back-arc stress: A comparison between laboratory models and current subduction zones, Earth and Planetary Science Letters, 256(3), 473-483.

Hodson, K. R. (2012), Morphology, exhumation, and Holocene erosion rates from a tropical glaciated mountain range: the Cordillera Blanca, Peru, 1-94 pp. McGill University Masters of science.

Jaillard, E. (1993), L'évolution tectonique de la marge péruvienne au Sénonien et Paleocène et ses relations avec la géodynamique. Bulletin-Société Géologique de France, 164, 819819.

Jaillard, E. (1994), Kimmeridgian to Paleocene tectonic and geodynamic evolution of the Peruvian (and Ecuadorian) margin, In Cretaceous tectonics of the Andes, edited by J. A. Salfity, pp. 101-167, Vieweg, Teubner Verlag.

Jaillard, E., and P. Soler (1996), Cretaceous to early Paleogene tectonic evolution of the northern Central Andes $\left(0-18^{\circ} \mathrm{S}\right)$ and its relations to geodynamics, Tectonophysics, 
James, D. E. (1971), Plate tectonic model for the evolution of the Central Andes, Geological Society of America Bulletin, 82, 3325-3346.

Jordan, T. E., B. L. Isacks, R. W. Allmendinger, J. A. Brewer, V. A. Ramos, and C. J. Ando (1983), Andean tectonics related to geometry of subducted Nazca plate, Geological Study of America Bulletin, 94, 341-361.

Kay, R. W., and S. M. Kay (2002), Andean adakites: three ways to make them, Acta Petrologica Sinica.

Lacombe, O. (2012), Do fault slip data inversions actually yield "paleostresses" that can be compared with contemporary stresses? A critical discussion, Comptes Rendus Geoscience, 344(3-4), 159-173, doi:10.1016/j.crte.2012.01.006.

Margirier, A., X. Robert, L. Audin, C. Gautheron, M. Bernet, S. Hall, and T. Simon-Labric (2015), Slab flattening, magmatism and surface uplift in the Cordillera Occidental (northern Peru), Geology, 1-4, doi:10.1130/G37061.1.

Margirier, A., L. Audin, X. Robert, F. Herman, J. Ganne and S. Schwartz (2016), Time and mode of exhumation of the Cordillera Blanca batholith (Peruvian Andes), Journal of Geophysical Research: Solid Earth, 121, doi:10.1002/2016JB013055.

Marrett, R., and R. W. Allmendinger (1990), Kinematic analysis of fault-slip data, Journal of Structural Geology, 12(8), 973-986.

Martinod, J., L. Husson, P. Roperch, B. Guillaume, and N. Espurt (2010a), Horizontal subduction zones, convergence velocity and the building of the Andes, Earth and Planetary Science letters, 299(3-4), 299-309, doi:10.1016/j.eps1.2010.09.010.

McKee, E. H., and D. C. Noble (1982), Miocene volcanism and deformation in the western

McNulty, B. A., and D. L. Farber (2002), Active detachment faulting above the Peruvian flat Cordillera and high plateaus of south-central Peru, Geological Society of America Bulletin, 93(8), 657-662. slab, Geology, 30(6), 567-570.

McNulty, B. A., D. L. Farber, G. S. Wallace, R. Lopez, and O. Palacios (1998), Role of plate kinematics and plate-slip-vector partitioning in continental magmatic arcs: Evidence from the Cordillera Blanca, Peru, Geology, 26(9), 827-830.

Mégard, F. (1978), Etude géologique des Andes du Pérou central: Mémoire ORSTROM, 86.

Mégard, F. (1984), The Andean orogenic period and its major structures in central and northern Peru, Journal of the Geological Society, 141(5), 893-900.

Mégard, F., D. C. Noble, E. H. McKEE, and H. Bellon (1984), Multiple pulses of Neogene compressive deformation in the Ayacucho intermontane basin, Andes of central Peru, Geological Society of America Bulletin, 95(9), 1108-1117. 
Müller, R. D., M. Sdrolias, C. Gaina, and W. R. Roest (2008), Age, spreading rates, and spreading asymmetry of the world's ocean crust, Geochem. Geophys. Geosyst., 9(4), 119, doi:10.1029/2007GC001743.

Noble, D. C., E. H. McKee, T. Mourier, and F. Mégard (1990), Cenozoic stratigraphy, magmatic activity, compressive deformation, and uplift in northern Peru, Geological Society of America Bulletin, 102(8), 1105-1113.

Nocquet, J.-M. et al. (2014), Motion of continental slivers and creeping subduction in the northern Andes, Nature Geoscience, 7(4), 287-291, doi:10.1038/ngeo2099.

Ortner, H., F. Reiter, and P. Acs (2002), Easy handling of tectonic data: the programs TectonicVB for Mac and TectonicsFP for Windows ${ }^{\mathrm{TM}}$, Computers \& Geosciences, 28(10), 1193-1200.

Pardo-Casas, F., and P. Molnar (1987), Relative motion of the Nazca (Farallon) and South American plates since Late Cretaceous time, Tectonics, 6(3), 233-248.

Petford, N., and M. P. Atherton (1992), Granitoid emplacement and deformation along a major crustal lineament: the Cordillera Blanca, Peru, Tectonophysics, 205(1), 171-185.

Pêcher, A. et al. (2008), Stress field evolution in the northwest Himalayan syntaxis, northern Pakistan, Tectonics, 27(6), n/a-n/a, doi:10.1029/2007TC002252.

Ramos, V. A., and A. Folguera (2009), Andean flat-slab subduction through time, Geological Society, London, Special Publications, 327(1), 31-54, doi:10.1144/SP327.3.

Ramos, V. A., E. O. Cristallini, and D. J. Pérez (2002), The Pampean flat-slab of the Central Andes, Journal of South American Earth Sciences, 15(1), 59-78.

Rosenbaum, G., D. Giles, M. Saxon, P. G. Betts, R. F. Weinberg, and C. Duboz (2005), Subduction of the Nazca Ridge and the Inca Plateau: Insights into the formation of ore deposits in Peru, Earth and Planetary Science letters, 239(1-2), 18-32, doi:10.1016/j.eps1.2005.08.003.

Ruff, L. J. (1989), Do trench sediments affect great earthquake occurrence in subduction zones? Subduction Zones Part II, 129(1-2), 264-282.

Ruff, L. J., and H. Kanamori (1983), Seismic coupling and uncoupling at subduction zones, Tectonophysics, 99(2-4), 99-117.

Saillard, M., L. Audin, B. Rousset, J. P. Avouac, M. Chlieh, S. R. Hall, L. Husson, and D. L. Farber (2017), From the seismic cycle to long-term deformation: linking seismic coupling and Quaternary coastal geomorphology along the Andean megathrust, Tectonics, 36(2), 241-256, doi:10.1029/2002JB002072.

Schellart, W. P. (2008), Overriding plate shortening and extension above subduction zones: A parametric study to explain formation of the Andes Mountains, Geological Society of America Bulletin, 120(11-12), 1441-1454.

Scheuber, E., and G. Gonzalez (1999), Tectonics of the Jurassic- Early Cretaceous magmatic arc of the north Chilean Coastal Cordillera $\left(22^{\circ}-26^{\circ} \mathrm{S}\right)$ : A story of crustal deformation along a convergent plate boundary, Tectonics, 18(5), 895-910.

640 Schwartz, D. P. (1988), Paleoseismicity and neotectonics of the Cordillera Blanca fault zone, 
Sébrier, M., J. L. Mercier, J. Macharé, D. Bonnot, J. Cabrera, and J. L. Blanc (1988), The state of stress in an overriding plate situated above a flat slab: The Andes of Central Peru, Tectonics, 7(4), 895-928.

645

Siame, L. L., M. Sébrier, O. Bellier, and D. Bourles (2006), Can cosmic ray exposure dating reveal the normal faulting activity of the Cordillera Blanca Fault, Peru? Revista de la Asociación Geológica Argentina, 61(4), 536-544.

Silgado, E. F. (1992), Investigaciones de sismicidad histórica en la América del Sur en los siglos XVI, XVII, XVIII y XIX, Consejo Nacional de Ciencia y Tecnología, Lima.

Somoza, R. (1998), Updated Nazca (Farallon)—South America relative motions during the last 40 My: implications for mountain building in the central Andean region, Journal of South American Earth Sciences, 11(3), 211-215.

Soulas, J. P. (1977), Las fases tectonicas del Terciario Superior en Peru-corte AyacuchoPisco, Boletin Sociedad Geológica del Perú, 57-58.

Sperner, B., L. Ratschbacher, and R. Ott (1993), Fault-striae analysis: a Turbo Pascal program package for graphical presentation and reduced stress tensor calculation, Computers \& Geosciences, 19(9), 1361-1388.

Steinmann, G. (1929), Geologie von Peru, In Heidelberg, edited by K. Winter, pp. 448.

Stewart, J. W., J. F. Evernden, and N. J. Snelling (1974), Age determinations from Andean Peru: a reconnaissance survey, Geological Society of America Bulletin, 85(7), 1107-1116.

Taylor, G. K., J. Grocott, A. Pope, and D. E. Randall (1998), Mesozoic fault systems, deformation and fault block rotation in the Andean forearc: a crustal scale strike-slip duplex in the Coastal Cordillera of northern Chile, Tectonophysics, 299(1), 93-109.

Wallace, R. E. (1951), Geometry of shearing stress and relation to faulting, The journal of Geology, 118-130.

Wipf, M. (2006), Evolution of the Western Cordillera and Coastal Margin of Peru: Evidence from low-temperature Thermochronology and Geomorphology, 1-163 pp. Swiss Federal Institute of Technology Zürich, 7 March.

Wise, J. M., and D. C. Noble (2003), Geomorphic evolution of the Cordillera Blanca, Northern Peru, Boletin de la sociedad Geologica del Peru, 96, 1-21.

Yamaji, A. (2000), The multiple inverse method: a new technique to separate stresses from heterogeneous fault-slip data, Journal of Structural Geology, 22(4), 441-452, doi:10.1016/S0191-8141(99)00163-7.

Zeilinger, G., J. P. Burg, N. Chaudhry, H. Dawood and S. Hussain (2000), Fault systems and Paleo-stress tensors in the Indus Suture Zone (NW Pakistan), Journal of Asian Earth Sciences, 18, 547-559. 


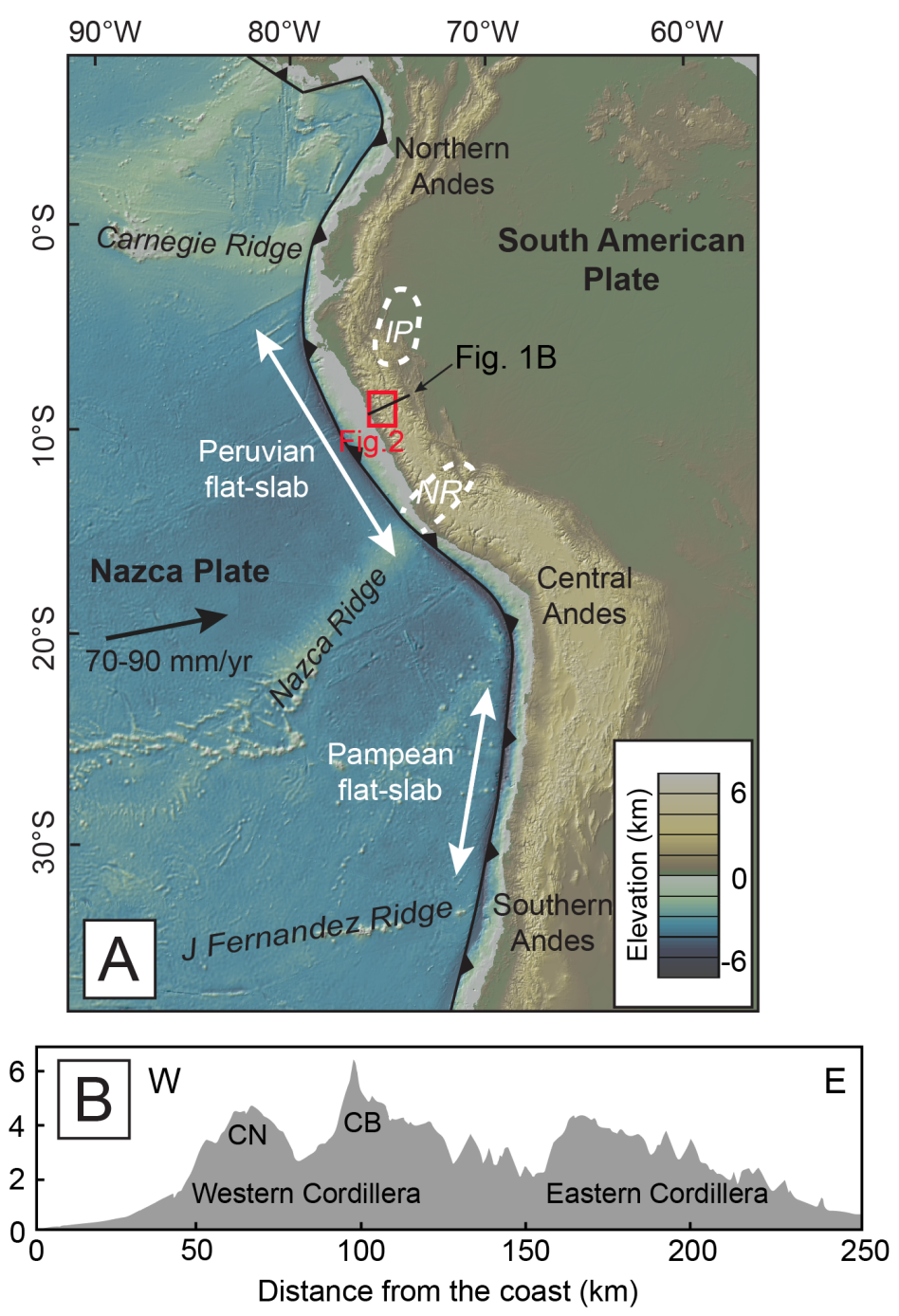

678 Figure 1: A) Topographic map of the Andes (SRTM data) including flat slab segments and 679 bathymetric features as the Nazca Ridge (NR) and the Inca plateau (IP; Inca Plateau location 680 after Gutscher et al. (1999)). The study area is indicated by the red rectangle. B) Topographic 681 cross-section of the Peruvian Andes at the latitude of the Cordillera Blanca showing the 682 Cordillera Blanca $(\mathrm{CB})$, the Cordillera Negra $(\mathrm{CN})$, the Western Cordillera and the Eastern 683 Cordillera. 

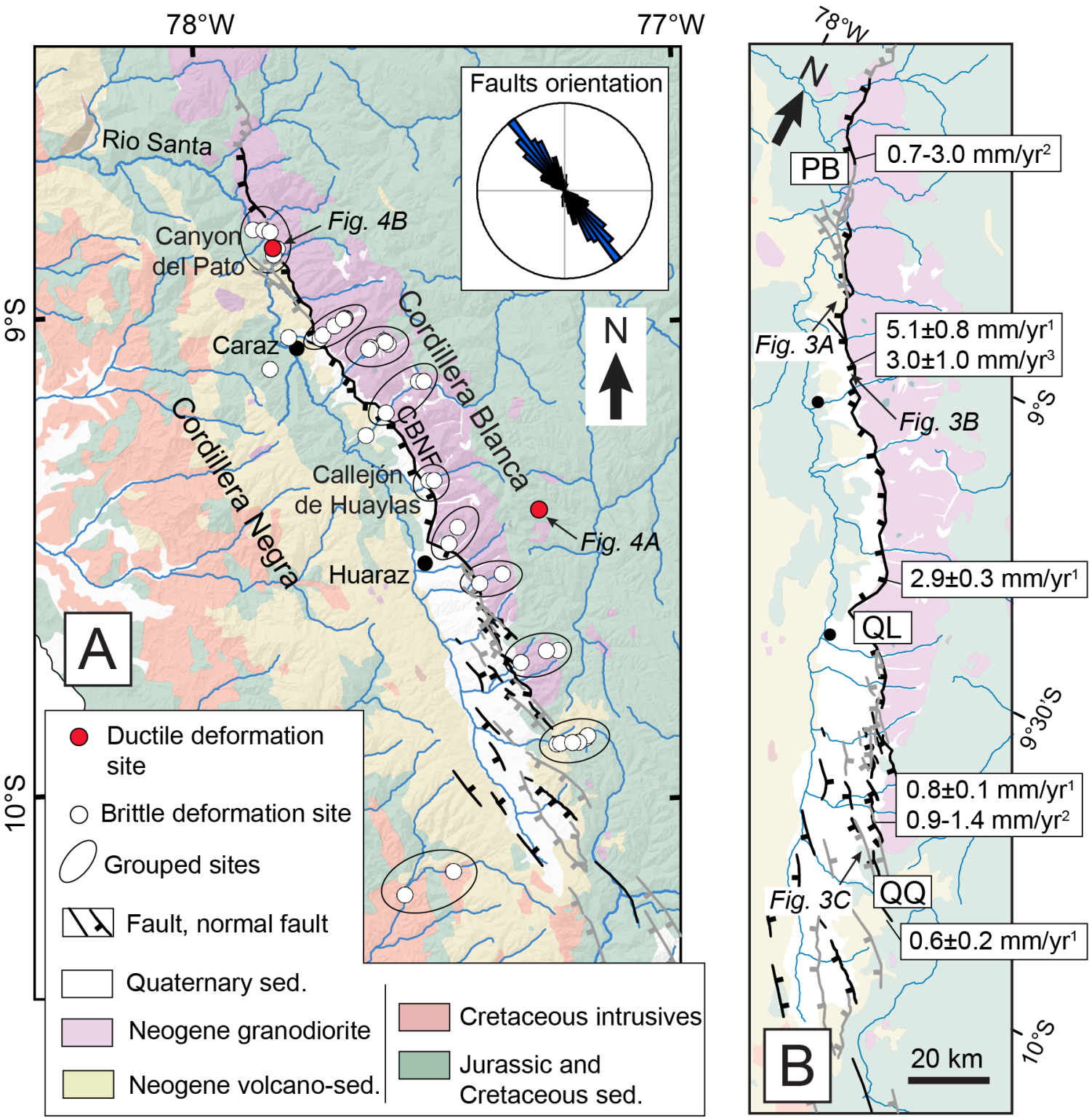

684

685 Figure 2: Geological maps of the study area. A) Map showing the active faults mapped in this study (black lines) and from Neotectonic Open Database (grey lines), the measurement

687 stations (white dot), the grouped sites and the sites where ductile deformation was analyzed 688 (red dot). Inset shows a rose diagram of the fault segments azimuth B) Zoom on the CBNF 689 with Quaternary vertical slip-rates from ${ }^{1}$ Farber and Hancock (in prep), ${ }^{2}$ Schwartz (1988) and $690{ }^{3}$ Siame et al. (2006) and location of bedrock slickensides measurement sites along the CBNF 691 (Pachma Bajo, PB; Quebrada Llaca, QL and Quebrada Querococha, QQ). 

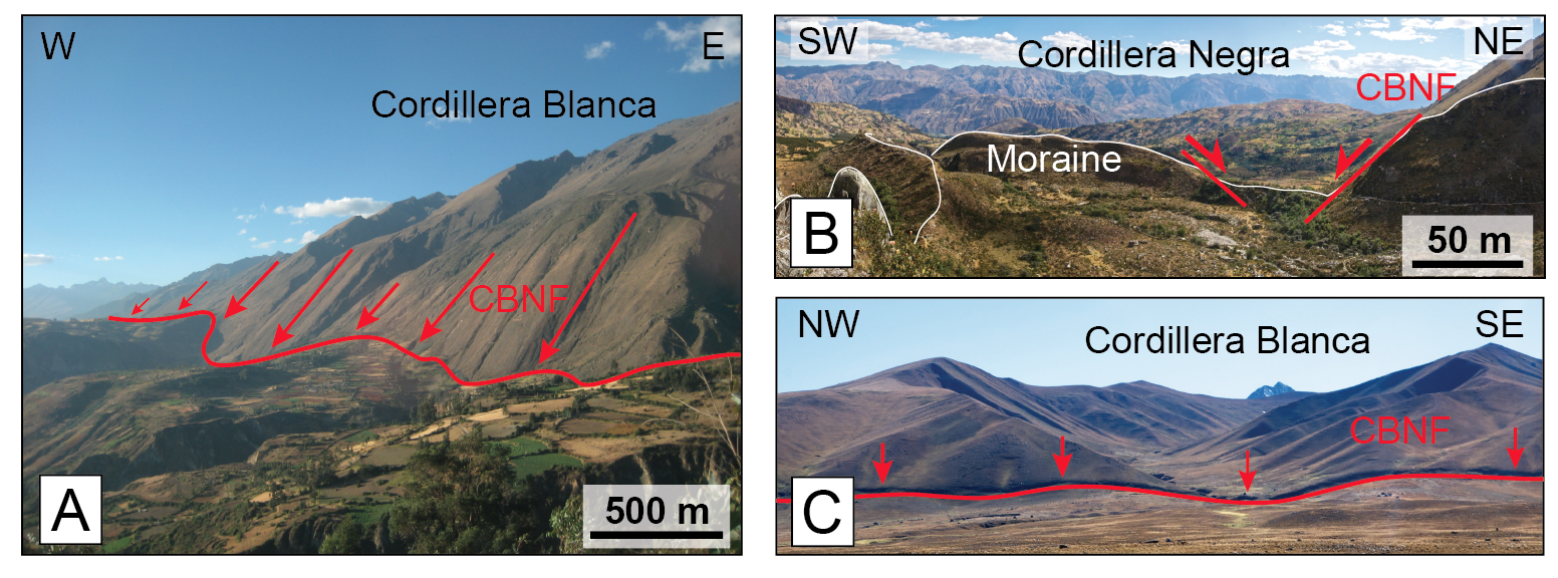

693 Figure 3: Photographs of the CBNF. See the Figure 2B for locations. A) Triangular facets in 694 the northern part of the Cordillera Blanca (1000 m high). B) Moraine offset at the outlet of the 695 Quebrada Huaytapallana (offset $\sim 100 \mathrm{~m}$ ). C) Quaternary scarp in the Lloclla Formation 696 (southern Cordillera Blanca) (offset $\sim 4 \mathrm{~m}$ ). 

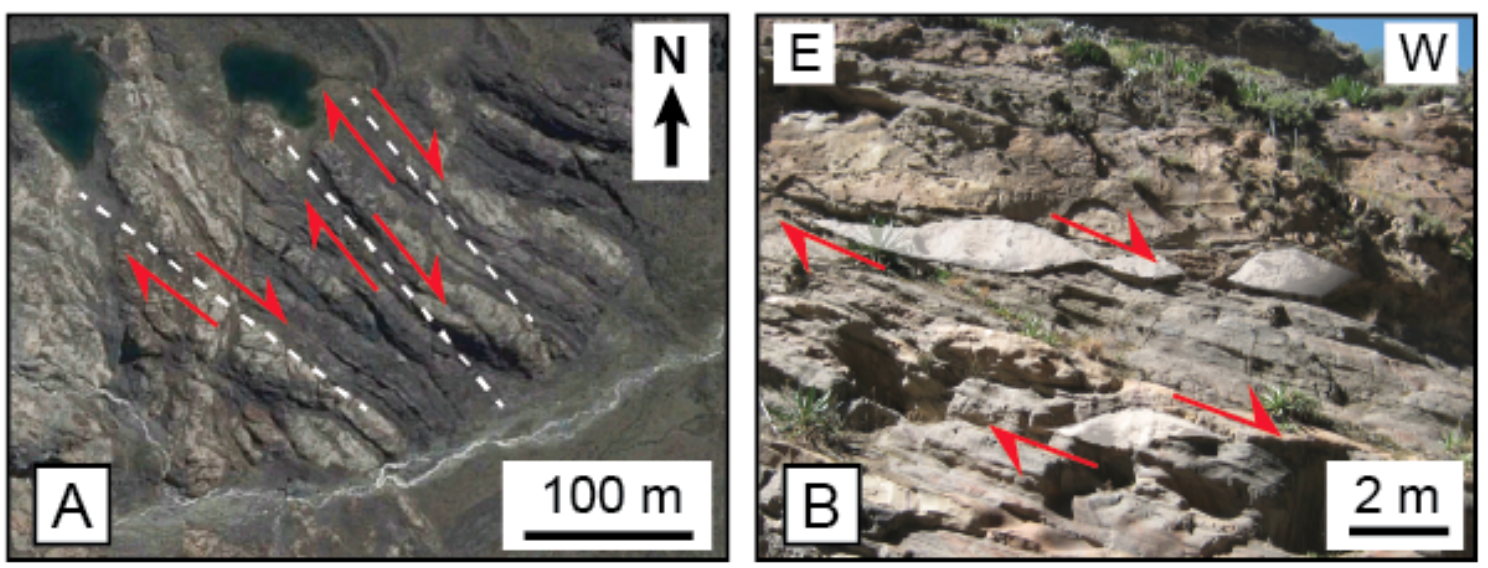

698 Figure 4: Ductile deformation in the Cordillera Blanca (see Figure 2 for location). A) Google

699 Earth Landsat image with dextral strike-slip in the eastern Cordillera Blanca, about $20 \mathrm{~km}$

700 East from the CBNF. B) Photograph of the ductile deformation of dykes in the cliffs of the 701 Canyon del Pato, in the CBNF zone. 
703

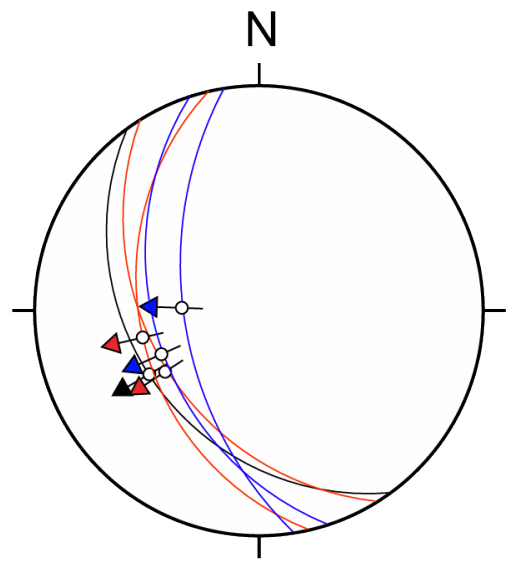

704 Figure 5: Cordillera Blanca fault planes and striaes orientation and dip, Wulff lower 705 hemisphere stereographic projection. Measurements were done in Pachma Bajo (PB; blue), 706 Quebrada Llaca (QL; black) and Quebrada Querococha (QQ; red), see figure 2B for the 707 location of the sites. 


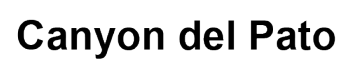

$$
\mathrm{n}=60 \quad \phi=0.68
$$

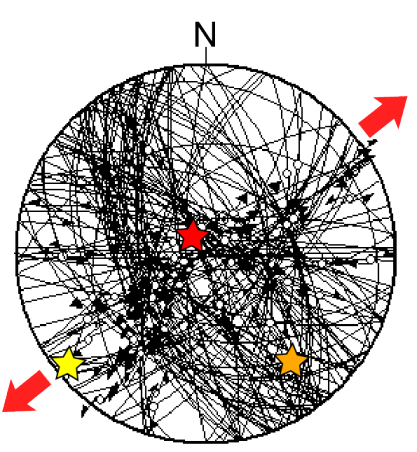

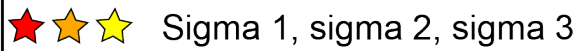

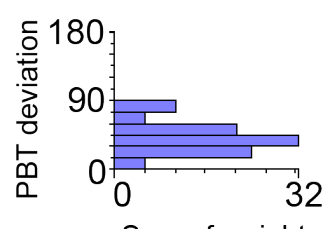

$\Rightarrow$ Extension direction

$\leftarrow$ Compression direction
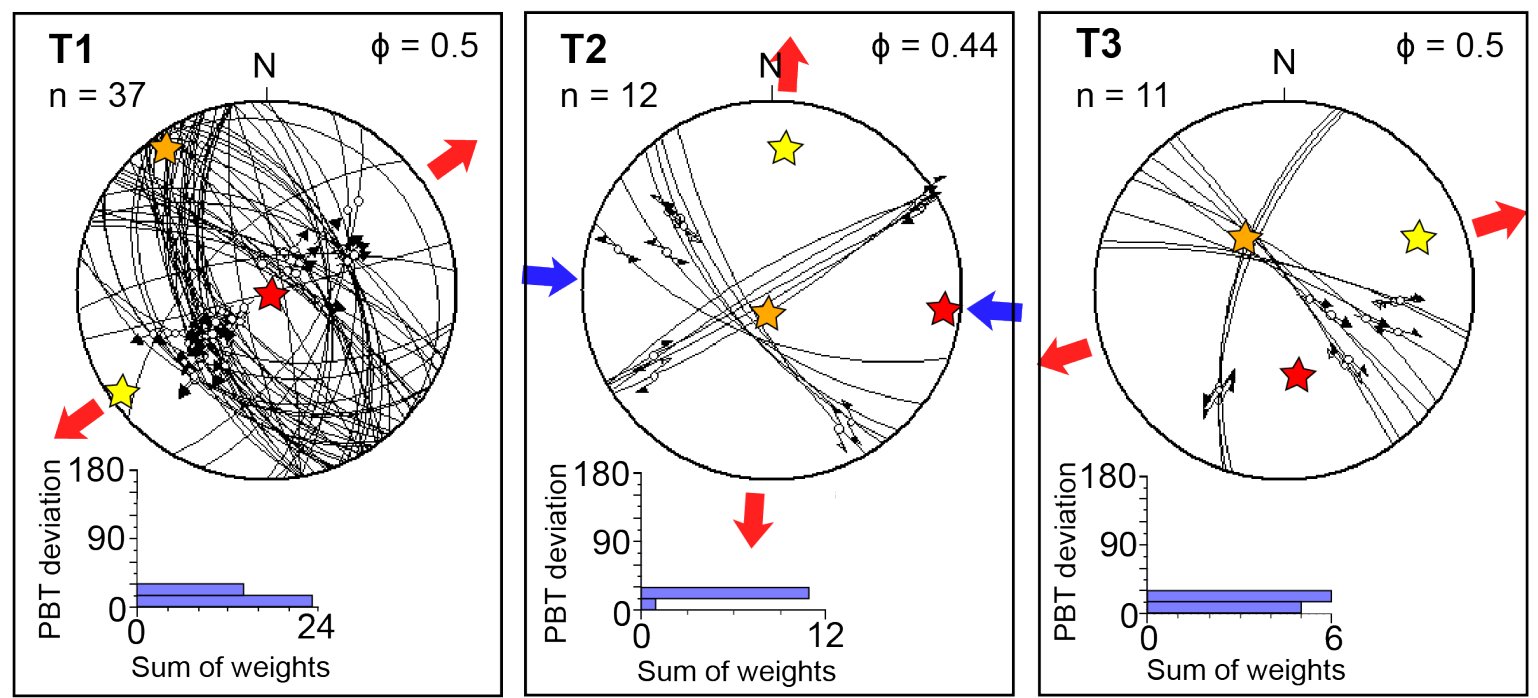

709 Figure 6: Faults in the Canyon del Pato (Cordillera Blanca), Wulff lower hemisphere

710 stereographic projection. A) All faults measurements and associated tensor calculation (PBT

711 method) the angular deviation is shown by the histogram, $n$ corresponds to the number of

712 fault measurements for each tensor, Phi corresponds to a shape parameter defined here as $P h i$

$713=\left(\sigma_{2}-\sigma_{3}\right) /\left(\sigma_{1}-\sigma_{3}\right)$. B-D) Tensors T1, T2, T3 and related fault-slickenline pairs (see text for 714 tensor determination method). 

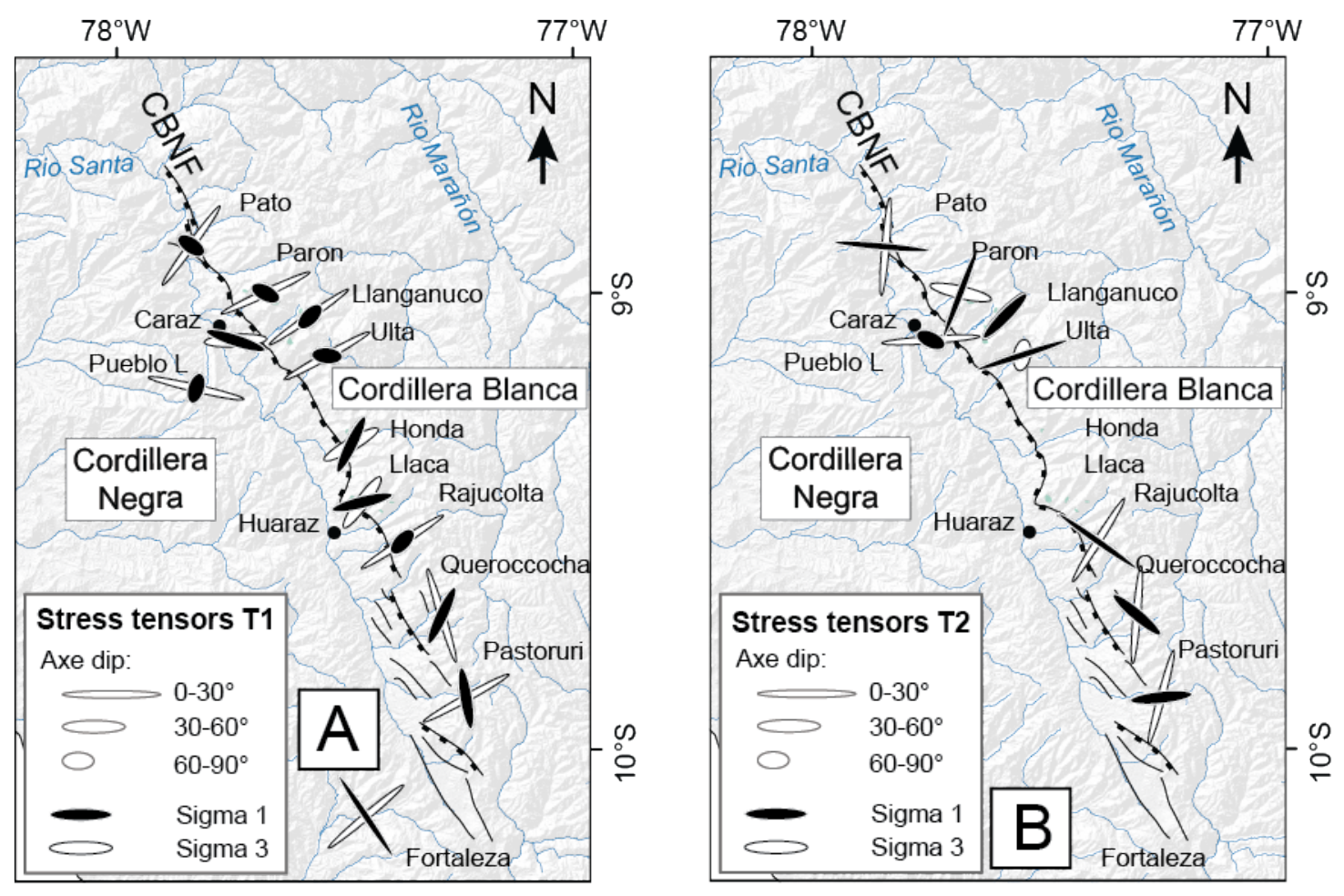

716 Figure 7: Stress orientation for grouped sites in the Cordillera Blanca region. Stress tensors

717 were calculated using all the fault-slickenline pairs available in one region. Ellipses represents

718 the stress ( $\sigma_{1}$ in black, $\sigma_{3}$ in white), the direction of the ellipse great axis corresponds to the

719 azimuth of the stress axis; the shape of the ellipse gives the plunge. The two best stress

720 tensors are shown on the maps. A) Stress tensors T1, B) Stress tensors T2. 

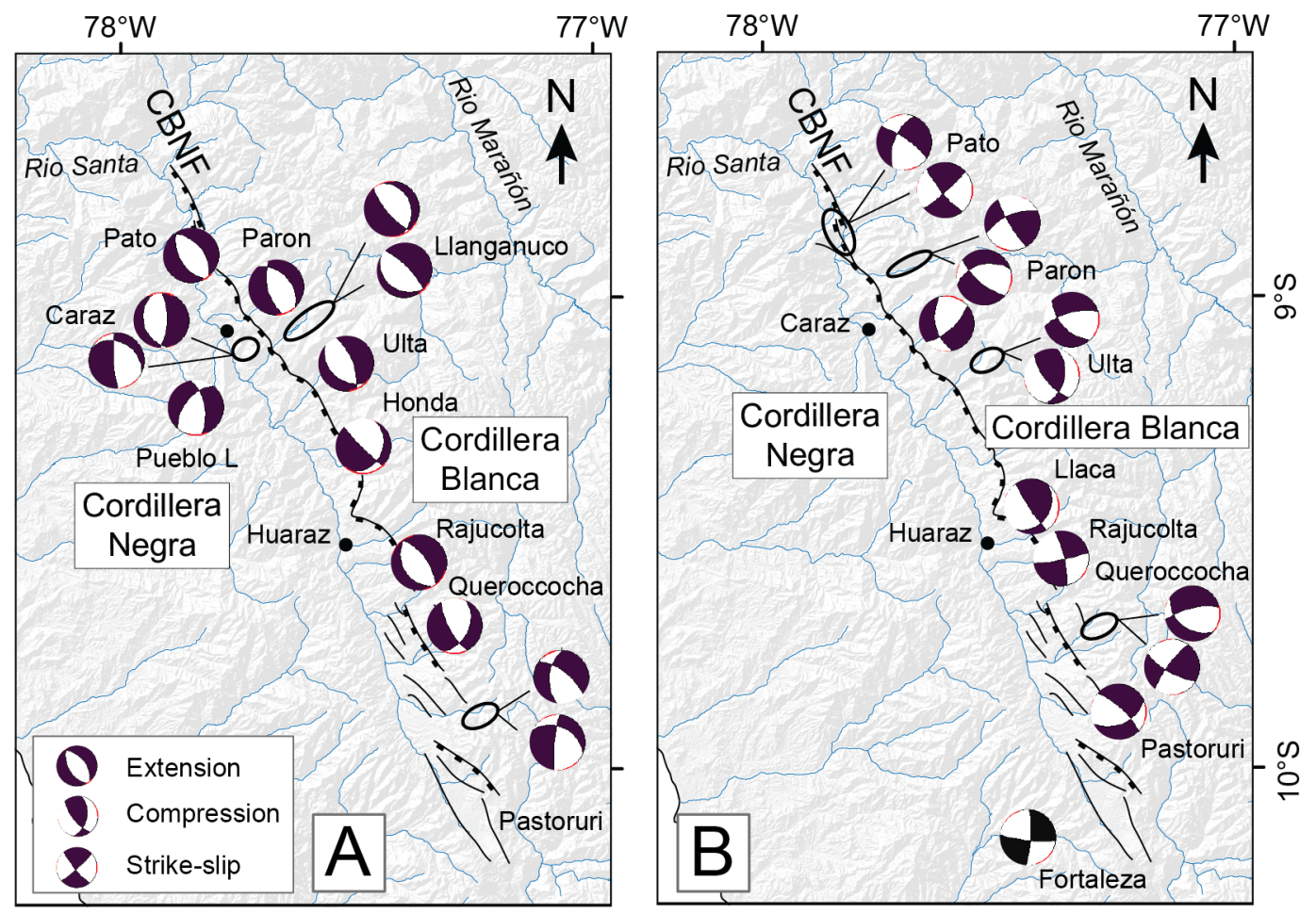

722 Figure 8: Stress tensors for grouped stations. A) Stress tensors corresponding to the present 723 day regional stress tensor (NE-SW extension) inferred from microearthquakes survey

724 (Deverchère et al., 1989). B) Other stress tensors recorded by the brittle deformation. 


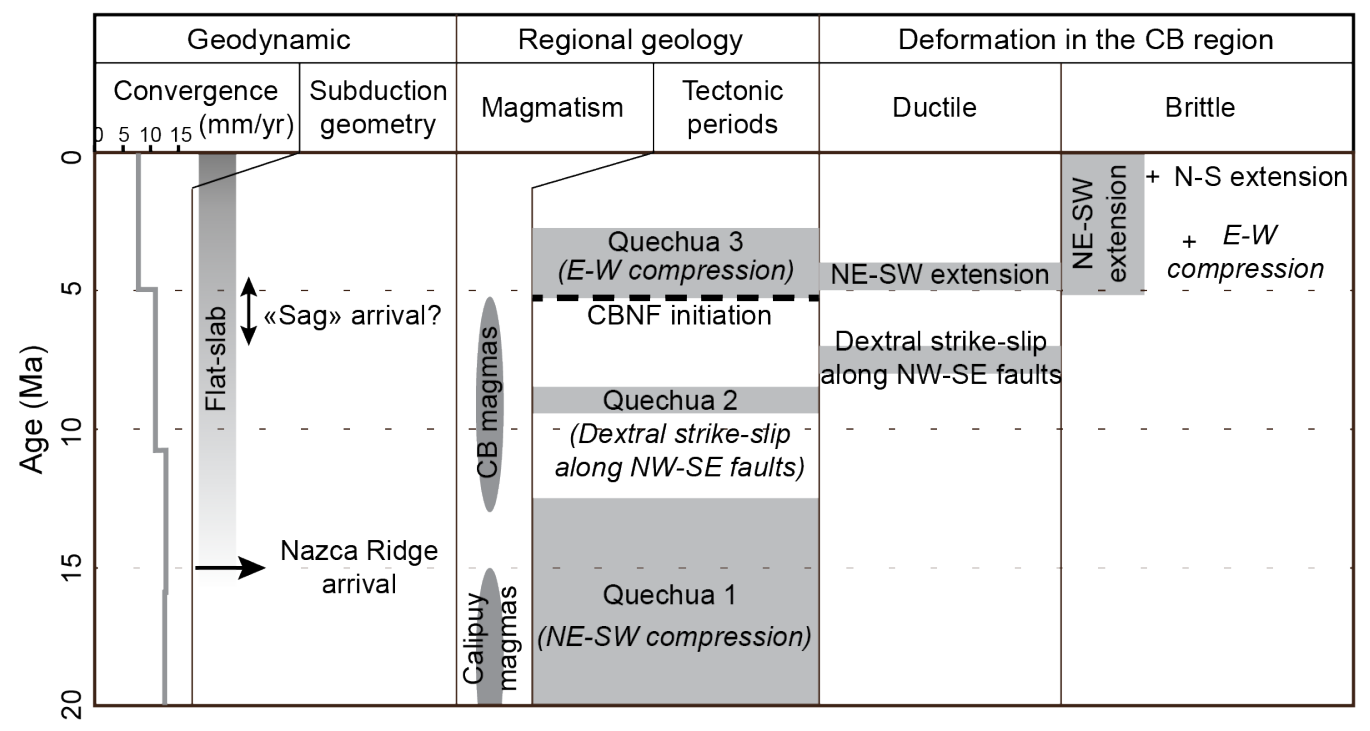

726 Figure 9: Schematic table that summarizes the northern Peru geodynamic events, regional

727 geology and results of stress field analyzes for the past $20 \mathrm{Ma}$. The table includes the mean

728 convergence rate (Somoza, 1998), subduction geometry (Barazangi and Isacks, 1976;

729 Gutscher et al., 1999; Rosenbaum et al., 2005; Margirier et al., 2015), magmatism age (e.g.,

730 Cobbing et al., 1981; Mukasa, 1984; Beckinsale et al., 1985), tectonic phases (e.g., Mégard,

731 1984) and our ductile and brittle deformation results. 
Table 1

Stress tensors from grouped sites.

\begin{tabular}{|c|c|c|c|c|c|c|c|c|c|c|}
\hline \multirow[t]{2}{*}{ Site } & \multirow[t]{2}{*}{ Tensor } & \multirow{2}{*}{$\begin{array}{l}\text { Number of couples } \\
\text { fault/striation }\end{array}$} & \multicolumn{4}{|c|}{ PBT } & \multicolumn{4}{|c|}{ Right diedra } \\
\hline & & & Phi & Sigma 1 & Sigma 3 & $\begin{array}{c}\text { Maximum angular } \\
\text { deviation }\left({ }^{\circ}\right)\end{array}$ & Phi & Sigma 1 & Sigma 3 & $\begin{array}{c}\text { Maximum angular } \\
\text { deviation }\left({ }^{\circ}\right)\end{array}$ \\
\hline \multirow[t]{4}{*}{ Canyo } & & 128 & & & & & & & & \\
\hline & T1 & 66 & 0.53 & $85 / 146$ & $01 / 234$ & 30 & 0.51 & $77 / 149$ & $00 / 058$ & 30 \\
\hline & T2 & 12 & 0.44 & $04 / 095$ & $15 / 005$ & 28 & 0.42 & $15 / 090$ & $11 / 357$ & 32 \\
\hline & $\mathrm{T} 3$ & 11 & 0.50 & $38 / 171$ & $14 / 068$ & 29 & 0.64 & $42 / 181$ & $25 / 066$ & 25 \\
\hline \multirow[t]{4}{*}{ Caraz } & & 34 & & & & & & & & \\
\hline & T1 & 9 & 0.53 & $53 / 108$ & $31 / 251$ & 33 & 0.67 & $54 / 106$ & $33 / 259$ & 24 \\
\hline & T2 & 10 & 0.58 & $66 / 295$ & $20 / 086$ & 34 & 0.55 & $62 / 328$ & $19 / 099$ & 34 \\
\hline & $\mathrm{T} 3$ & 8 & 0.70 & $07 / 265$ & $74 / 165$ & 42 & 0.69 & $00 / 264$ & $67 / 174$ & 30 \\
\hline \multicolumn{2}{|c|}{ Pueblo Libre } & 12 & & & & & & & & \\
\hline & T1 & 12 & - & - & - & - & 0.62 & $61 / 197$ & $02 / 103$ & 30 \\
\hline & & 60 & & & & & & & & \\
\hline & $\mathrm{T} 1$ & 15 & 0.48 & $72 / 117$ & $12 / 245$ & 33 & 0.32 & $65 / 124$ & $17 / 255$ & 27 \\
\hline & $\mathrm{T} 2$ & 16 & 0.45 & $12 / 201$ & $31 / 103$ & 34 & 0.44 & $10 / 194$ & $31 / 098$ & 30 \\
\hline & $\mathrm{T} 3$ & 6 & 0.51 & $56 / 085$ & $14 / 197$ & 26 & 0.67 & $60 / 081$ & $17 / 202$ & 26 \\
\hline \multicolumn{2}{|c|}{ Quebrada Llanganuco } & 58 & & & & & & & & \\
\hline & $\mathrm{T} 1$ & 23 & 0.50 & $65 / 045$ & $25 / 235$ & 34 & 0.56 & $59 / 104$ & $17 / 226$ & 43 \\
\hline & $\mathrm{T} 2$ & 8 & 0.50 & $52 / 010$ & $06 / 109$ & 32 & 0.56 & $58 / 006$ & $07 / 108$ & 32 \\
\hline \multirow[t]{4}{*}{ Quebr } & & 63 & & & & & & & & \\
\hline & T1 & 27 & 0.50 & $70 / 275$ & $17 / 061$ & 33 & 0.56 & $66 / 282$ & $17 / 053$ & 35 \\
\hline & $\mathrm{T} 2$ & 13 & 0.49 & $12 / 252$ & $62 / 011$ & 30 & 0.46 & $07 / 258$ & $79 / 027$ & 32 \\
\hline & $\mathrm{T} 3$ & 6 & 0.50 & $52 / 112$ & $10 / 011$ & 29 & 0.50 & $61 / 103$ & $10 / 355$ & 37 \\
\hline \multicolumn{2}{|c|}{ Quebrada Honda } & 15 & & & & & & & & \\
\hline & T1 & 9 & 0.44 & $50 / 026$ & $32 / 240$ & 31 & 0.25 & $43 / 033$ & $39 / 254$ & 26 \\
\hline \multicolumn{2}{|c|}{ Quebrada Llaca } & 14 & & & & & & & & \\
\hline & T1 & 6 & 0.50 & $32 / 256$ & $50 / 036$ & 27 & 0.67 & $01 / 123$ & $56 / 031$ & 44 \\
\hline \multicolumn{2}{|c|}{ Quebrada Rajucolta } & 21 & & & & & & & & \\
\hline & $\mathrm{T} 1$ & 7 & 0.50 & $76 / 223$ & $14 / 057$ & 24 & 0.57 & $69 / 225$ & $21 / 058$ & 35 \\
\hline & $\mathrm{T} 2$ & 7 & 0.56 & $16 / 305$ & $04 / 212$ & 24 & 0.57 & $13 / 303$ & $09 / 211$ & 19 \\
\hline \multicolumn{2}{|c|}{ Quebrada Queroccocha } & 70 & & & & & & & & \\
\hline & $\mathrm{T} 1$ & 15 & 0.50 & $59 / 025$ & $24 / 163$ & 30 & 0.47 & $68 / 032$ & $18 / 251$ & 39 \\
\hline & $\mathrm{T} 2$ & 16 & 0.44 & $59 / 130$ & $19 / 005$ & 32 & 0.34 & $67 / 146$ & $16 / 013$ & 32 \\
\hline & T3 & 8 & 0.61 & $05 / 346$ & $27 / 080$ & 30 & 0.62 & $12 / 346$ & $28 / 083$ & 25 \\
\hline & $\mathrm{T} 4$ & 6 & 0.54 & $07 / 041$ & $10 / 133$ & 33 & 0.67 & $04 / 229$ & $22 / 137$ & 31 \\
\hline \multicolumn{2}{|c|}{ Quebrada Pastoruri } & 89 & & & & & & & & \\
\hline & $\mathrm{T} 1$ & 25 & 0.57 & $57 / 171$ & 11/061 & 34 & 0.60 & $52 / 162$ & $12 / 056$ & 31 \\
\hline & T2 & 16 & 0.46 & $50 / 264$ & $18 / 015$ & 33 & 0.50 & $35 / 258$ & $29 / 011$ & 33 \\
\hline & $\mathrm{T} 3$ & 6 & 0.63 & $46 / 125$ & $29 / 232$ & 28 & 0.75 & $50 / 123$ & $30 / 257$ & 21 \\
\hline \multirow{2}{*}{\multicolumn{2}{|c|}{ Fortaleza Valley }} & 14 & & & & & & & & \\
\hline & & 7 & 0.55 & $17 / 326$ & $00 / 230$ & 35 & 0.50 & $31 / 312$ & $06 / 046$ & 38 \\
\hline
\end{tabular}

